\title{
THE AMERICAN GENERA OF SIMAROUBACEAE AND THEIR DISTRIBUTION
}

\author{
W. W. Thomas ${ }^{1}$
}

\begin{abstract}
RESUMO - Uma revisão das relações filogenéticas das subfamílias de Simaroubaceae é apresentada e os padrões de distribuição dos gêneros americanos são discutidos. As seis subfamílias de Engler são avaliadas e as três subfamílias com gêneros representados nas Américas são discutidas em detalhe. Os oito gêneros americanos incluem-se em três padrões gerais de distribuição: amplamente distribuídos nos neotrópicos; limitados ao norte da América do Sul; e com distribuição disjunta entre as Indias Ocidentais, América Central e México, e o sul da América do.Sul. Estas distribuições são discutidas e interpretadas.
\end{abstract}

Palavras-chave: Simaroubaceae, distribuição geográfica, flora neotropical.

ABSTRACT - A review of the phylogenetic relationships of the subfamilies of Simaroubaceae is presented and the distribution patterns of the American genera are discussed. Engler's six subfamilies are evaluated and the three subfamilies represented in the Americas and their included genera are discussed in detail. The eight American genera fall into three broad distributional categories: widely distributed throughout the neotropics, limited to northern South America, and disjunct between the West Indies, Central America and Mexico and southern South America. These distributions are discussed and interpreted.

Key-words: Simaroubaceae, distribution patterns, neotropical flora.

\section{Introduction}

The Simaroubaceae are a primarily tropical family of about 200 species (Cronquist 1981, Nooteboom 1962a) in 20-30 genera. The primary center of

1 - The New York Botanical Garden, Bronx, NY 10458-5126, USA. 
diversity for the family is in tropical America with a secondary center in tropical West Africa. The family is morphologically diverse and lacks any one feature common to all the genera and absent in related families. Most species are dioecious trees or shrubs with alternate compound leaves, five-parted flowers and drupaceous fruits.

The Simaroubaceae have close affinities with the Rutaceae, Burseraceae, Meliaceae and Cneoraceae. Collectively, these families comprise the narrowly defined Rutales of Dahlgren (1980) and Melchior (1964). Takhtajan's (1980) broader concept of the order includes many of Dahlgren's Sapindales, most notably the Anacardiaceae. Cronquist (1981) and Thorne (1983) both treat the rutalean and sapindalean groups as suborders of a more broadly conceived order (the Sapindales of Cronquist and the Rutales of Thorne). The Rutaceae are closest, having in common similar chemistry and wood anatomy; most Rutaceae differ from Simaroubaceae in having punctate glands and in the absence of quassinoid compounds (degraded triterpenoids unique to the Simaroubaceae). The Burseraceae and Anacardiaceae, although morphologically similar, differ from the Simaroubaceae in their resinous inner bark, distinct wood anatomy, and lack of quassinoids. The Meliaceae usually differ in having connate filaments and ovaries with only one style, but they are, overall, morphologically similar to the Simaroubaceae. The Rutaceae and Meliaceae both contain limonoids, triterpenes which resemble the precursors of the quassinoids found in the Simaroubaceae.

\section{The Subfamilies and Genera}

Engler (1931) divided the family into six subfamilies with one large subfamily, the Simarouboideae, comprising most of the genera, and five smaller subfamilies of one to three genera each. Cronquist (1944a, b, c, d) producedbrief treatments of the American genera with the exception of Picramnia. Below, Engler's subfamilies are used as a framework for discussing the American genera and their distributions.

Surianoideae: Suriana, Cadellia, and Guilfoylia (along with Stylobasium formerly placed in the Chrysobalanaceae) were moved by Cronquist (1981) and Dahlgren (1983) to the family Surianaceae which both authors place in the Rosales. This elevation from the rank of subfamily to family has gained general acceptance. Another genus, Recchia (Rigiostachys) was included by Engler (1931) and Cronquist (1944d) in the Surianoideae. Although Cronquist (1981) accepted the concept of a separate Surianaceae, he retained Recchia in the Simaroubaceae on the strength of its compound leaves and nectar disk. The recently described Recchia simplicifolia Wendt \& Lott, because of its simple leaves, may provide a link between that genus and the Surianaceae. The gyno- 
basic styles found in Recchia and in the three accepted genera of Surianaceae are anomalous in the Simaroubaceae and provide a strong argument for inclusion of Recchia in the Surianaceae.

Irvingioideae and Kirkioideae: Both are exclusively Old World groups whose inclusion in the Simaroubaceae is controversial.

Simarouboideae: This subfamily comprises most of the genera in the Americas, including Simaba, Simarouba, Quassia, Castela (including Holacantha), Picrasma, and Picrolemma (including Cedronia). The features that characterize this group are those that are considered typical attributes of the family: i.e., the presence of quassinoids, separate carpels with united styles, drupaceous fruits, appendaged filaments, and a tendency towards unisexual flowers. Simaba, Simarouba, and Quassia form a closely related group which Nooteboom (1962b) united, along with some Asian genera, into one genus under the name Quassia.

Alvaradoideae: This subfamily comprises the single genus, Alvaradoa, which includes five species. While the taxonomy of the genus is well-understood, its relationships to the rest of the Simaroubaceae are obscure. There does exist, however, one report of quassinoids from Alvaradoa (de Villatoro et al., 1974).

Picramnioideae: This subfamily also comprises a single genus, Picramnia, a New World genus of 40 species it was not studied by Cronquist and has not been revised since Engler's (1874) treatment for Flora Brasiliensis. It is under study now by Dr. J. R. Pirani and me, a collaboration which has resulted in treatments of the morphology of the genus and a revision of the Brazilian species (Pirani 1989), a conspectus of the Mexican and Central American species (Thomas 1988), and several new species (Pirani 1988; Pirani \& Thomas 1988; Thomas 1990).

Picramnia exibits several morphological similarities with Alvaradoa: pendent racemes (in many species), unisexual, small flowers with stamens alternate with the sepals, fused ovaries, and comparable wood anatomy. No quassionoids have ever been detected in Picramnia.

\section{Distribution of the American Genera}

The American genera of Simaroubaceae occur from Arizona, Texas and Florida in the southern United States south to northern Argentina. Although one introduced species, Ailanthus altissima (Miller) Swingle, is found in temperate regions, all native American species are either tropical or subtropical in occurrence. The native genera have distributions which fall into three general 
categories: 1) Neotropical, 2) Northern South America, and 3) Disjunct. As discussed earlier, the genera Suriana and Recchia, traditionally treated as members of the Simaroubaceae, are considered as belonging to the Surianaceae.

Neotropical: This distribution is used for genera occurring in several vegetation types and throughout the neotropics, in Mexico and Central America, the West Indies, and South America. The genera Simarouba, Picramnia, and Simaba exemplify this pattern.

Simaba: This is the second largest neotropical genus of Simaroubaceae with 24 species divided into three subgenera and is currently under study in collaboration with E. Franceschinelli. Although primarily restricted to Amazonian and planaltine South America, there are species in most of South America and one widespread species, $S$. cedron Planch., which is found as far north as Mexico.

Simarouba: A genus of five species, it is found from Florida (USA), Mexico and the Greater Antilles to Bolivia and the states of Minas Gerais and Espírito Santo in Brazil. Three clearly distinct species are each endemic to one of the Greater Antilles: Cuba, Hispaniola, and Puerto Rico; one species is found primarily in Mexico and Central America; and two are restricted to South America.

Picramnia: The largest genus of Simaroubaceae, the 40 species of $\mathrm{Pi}$ cramnia are found from Florida, Mexico, and the West Indies to southern Brazil and Paraguay. Practically all species are found in forests (with the exception of a couple of species found in the cerrado and campo rupestre of Brazil). Although there are many species which are quite widespread, many of the rest have very narrow distributions (see Pirani 1989, this symposium, Thomas 1990) which seem to correlate with "centers of endemism" as described by Prance (1982).

Northern South American: This distribution covers northern South America from the Amazon basin northward and including adjacent parts of Central America.

Picrolemma: This genus comprises two species, one known from Colombia and Peru and the other from the Amazon basin. The widespread P. sprucei Benth. occurs throughout lowland Amazonia. The other species, P. huberi Ducke, was for many years known only from the type. It has become clear to me recently, however, that it is conspecific with Cedronia granatensis Cuatr., a monotypic genus that is better considered as belonging to Picrolemma.

Quassia: This genus is widely used as a medicinal plant and has been so used for centuries. Because of this, its natural distribution is difficult to determine with confidence. The collections available to me show a more or less continuous distribution from the Guiana through Venezuela and Colombia north to Nicaragua. 


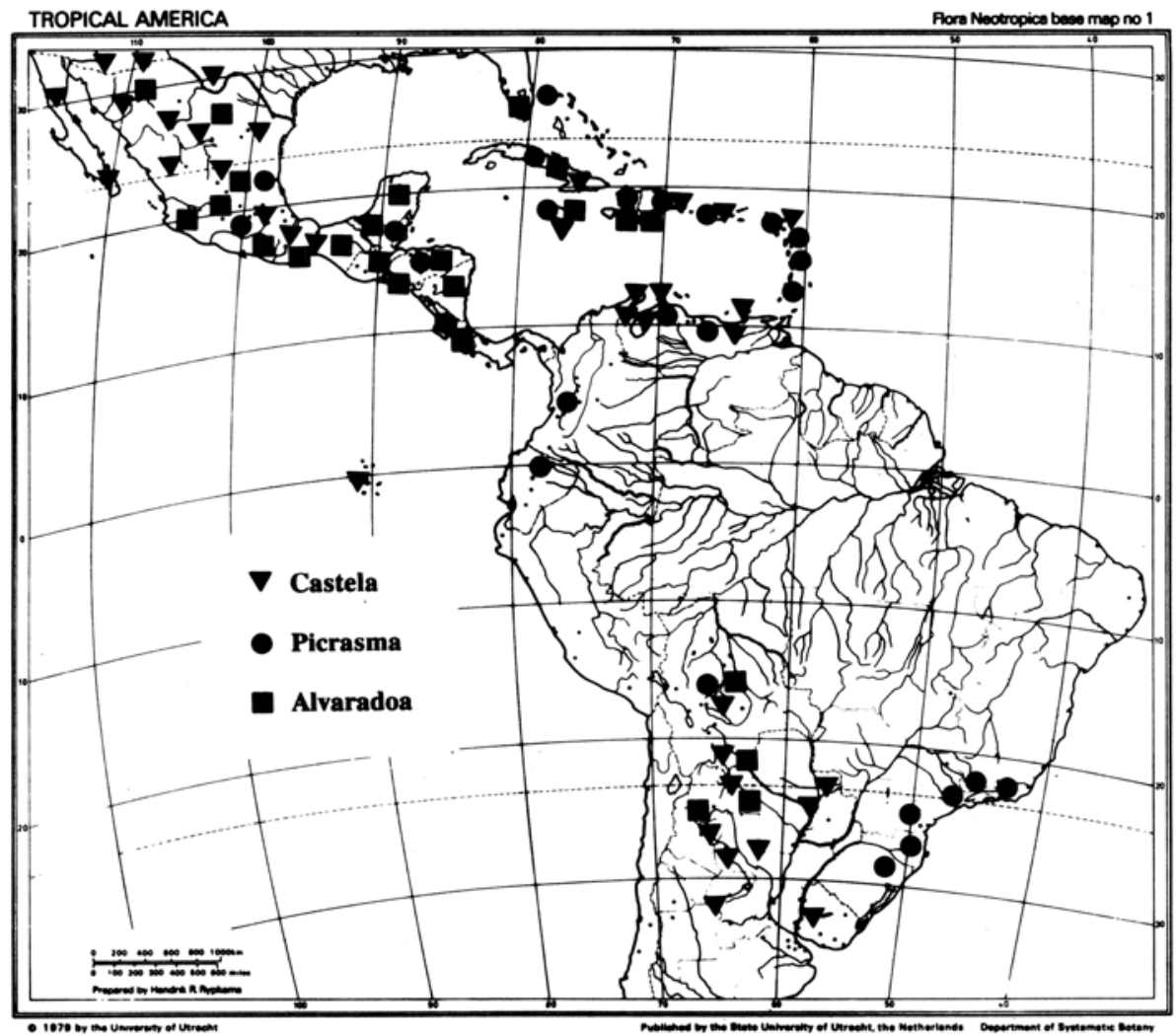

Figure 1 - Currently known distributions of the genera Alvaradoa, Castela, and Picrasma.

Disjunct: This pattern is primarily one where the genus is found in Central America and the West Indies (and occasionally in northernmost South America) as well as in southern South America (Fig. 1). Genera showing this pattern are Alvaradoa, Picrasma, and Castela. Alvaradoa and Castela are adapted to arid habitats while Picrasma is a genus of forests.

Alvaradoa: This is a genus of five species which are mostly geographically distinct. One species is restricted to southern South America from Argentina to Bolivia. Of the other four, one is found in southern Florida (USA), Cuba, the Bahamas, Central America and Mexico, and the three remaining ones are each endemic to a single island, one on Cuba, one on Hispaniola, and one on Jamaica.

Castela: In 1944(a), Cronquist recognized 12 species in this genus by maintaining several segregate species. The following year he aggregated three of 
these into one, $C$. erecta Turp., reducing the number of species to ten. Moran \& Felger (1968) discovered and described a new species which they referred to Castela but which they considered intermediate between Castela and the related Holacantha. On the weight of this intermediacy, they submerged the two existing species of Holacantha into Castela resulting in a total of thirteen species. Two of these are found in southern South America from Bolivia and Paraguay to Argentina and Brazil. Three are endemic to Cuba, one to Jamaica, and one to Hispaniola. Of the remaining six, four are found in the southwestern United States and Northern Mexico, one restricted to Oaxaca, Mexico, and the last, widespread Castela erecta with three subspecies, found from Texas to Mexico, the West Indies, northern South America, and the Galapagos Islands.

Picrasma: A genus of seven species, it has a distribution similar to that of Alvaradoa, with one species found in southern South America and the rest from northern South America north to Mexico and the West Indies. There are species endemic to Hispaniola, Cuba, Veracruz, Mexico, and the lesser Antilles. Another species is more widespread, found throughout the West Indies and south to northern South America. An undescribed species first detected by Cronquist (1944d) occurs in the northern Andes. A collection from Santa Cruz, Bolivia, indicates that more collecting from the Andean countries may fill in what is now a gap in distribution. This would leave the two genera of arid areas, Castela and Alvaradoa as the ones with disjunct distributions.

The disjunct distributions of Castela and Alvaradoa are consistent with the Trans-Tropical Disjunctions discussed by Solbrig (1972), Hunziger (1972), and Raven (1972). The mechanism leading to this distribution is probably best described as “... a sporadic, step-wise migration, operating at different times throughout the Tertiary and by different pathways, and resulting in a limited exchange of plant species and genera between North and South America" (Raven, 1972). While Hunziger (1972) argues for a pattern of migration of Larrea divaricata from South to North America, based in part on the greater diversity of the genus in South America, the diversity of the genera Alvaradoa and Castela is greater in North America. Although this might justify the conclusion that these genera of Simaroubaceae migrated from north to south, it is also possible that the greater area available in the north granted more opportunities for geographical isolation and speciation. Studies of these genera now underway may further elucidate these questions.

\section{Achnowledgments}

I wish to thank Dra. Ana Maria Giulietti and Dr. Enrique Forero for making this opportunity possible and the U.S.-Brazil initiative supported by the USDA and CNPq for funding the workshop. I would also like to thank Dr. José 
R. Pirani and Edivani Franceschinelli for sharing their thoughts on the systematics of Simaroubaceae.

\section{Bibliographic references}

CRONQUIST, A. 1944a. Studies in the Simaroubaceae I. The genus Castela. J. Arnold Arb. 25: 122-128.

CRONQUIST, A. 1944b. Studies in the Simaroubaceae - II. The genus Simarouba. Bull. Torrey Bot. Club 71: 226-234.

CRONQUIST, A. 1944c. Studies in the Simaroubaceae. III. The genus Simaba. Lloydia 7: 81-92.

CRONQUIST, A. 1944d. Studies in the Simaroubaceae - IV. Resume of the American genera. Brittonia 5: 128-147.

CRONQUIST, A. 1945. Additional notes on the Simaroubaceae. Brittonia 5: 469-470.

CRONQUIST, A. 1981. An Integrated System of Classification of the Flowering Plants. Columbia University Press, New York.

DAHLGREN, R. 1980. A revised system of classification of the Angiosperms. Bot. J. Linn. Soc. 80: 91-124.

ENGLER, A. 1874. Simarubaceae. In C. F. P. Martius (ed.) Flora Brasiliensis 12(2): 197-248. Munich.

ENGLER, A. 1931. Simarubaceae. Die Natürlichen Pflanzenfamilien, Band 19a: 359-405.

HUNZIGER; J. H.; PALACIOS, R. A.; VALESI, A. G. de \& POGIO, L. 1972. Species disjunctions in Larrea: Evidence from morphology, cytogenetics, phenolic compounds and seed albumins. Ann. Miss. Bot. Gard. 59(2): 224-233.

MELCHIOR, 1964. Simaroubaceae. In Melchior, H. (ed.) A. Engler's Syllabus der Pflanzenfamilien, 12th ed., 2: 262-277. Borntraeger, Berlin.

MORAN, R. \& FELGER, R. 1968. Castela polyandra, a new species in a new section; union of Holacantha with Castela (Simaroubaceae). Trans. San Diego Soc. Nat. Hist. 15(4): 31-40.

NOOTEBOOM, H. P. 1962a. Simaroubaceae. In Flora Malesiana, ser. 1, 6(2): 193226.

NOOTEBOOM, H. P. 1962b. Generic delimitation in Simaroubaceae tribus Simaroubeae and a conspectus of the genus Quassia L. Blumea 14: 309-315.

PIRANI, J. R. 1988. Uma nova espécie de Picramnia e notas sobre Picramnia campestris Rizz. \& Occh. (Simaroubaceae). Bolm Botânica, Univ. São Paulo 10: 7-13.

PIRANI, J. R. 1989. Revisão taxonômica de Picramnia (Simaroubaceae) no Brasil. Tese de Doutorado, Instituto de Biociências, Univ. de São Paulo, Brasil.

PIRANI, J. R. 1990. Diversidade taxonômica e padrões de distribuição geográfica em Picramnia (Simaroubaceae) no Brasil. Acta Botânica Brasilica 4.

PIRANI, J. R. \& THOMAS, W. W. 1988. Duas novas espécies de Picramnia (Simaroubaceae) para a flora do norte do Brasil. Bolm Mus. Par. Emilio Goeldi, sér. Bot. 4: 271-280.

PRANCE, G. T. 1982. Forest refuges: Evidence from woody angiosperms. In G. T. Prance (ed.) Biological Diversification in the Tropics. Columbia University Press, New York, p. 137-158. 
RAVEN, P. H. 1972. Plant species disjunctions: A summary. Ann. Miss. Bot. Gard. 59(2): 234-246.

SOLBRIG, O. T. 1972. The floristic disjunctions between the "Monte" in Argentina and the "Sonoran Desert" in Mexico and the United States. Ann. Miss. Bot. Gard. 59(2): 218-223.

TAHKTAJAN, A. 1980. Outline of the classification of the flowering plants (Magnoliophyta). Bot. Rev. 46(3): 225-359.

THOMAS, W. W. 1988. A conspectus of Mexican and Central American Picramnia (Simaroubaceae). Brittonia 40(1): 89-105.

THOMAS, W. W. 1990. A new Picramnia (Simaroubaceae) from Amazonian Peru. Brittonia 42: (in press).

THORNE, R. R. 1983. Proposed new realignments in the angiosperms. Nordic J. Bot. 3: 85-117.

VILLATORO, B. S.; GONZALES, F. G.; POLONSKY, J. \& BASKEVITCH-VARON, Z. 1974. Chrysophanic acid, chrysophanein and chapparin from Alvaradoa amorphoides. Phytochemistry 13: 2018-2019. 